\title{
Exploring Selected Cultures in Mitigating an Array of Social Vices in South Africa. A Literature Review
}

\author{
Prof Simon M. Kang'ethe \\ University of Fort Hare, P/B X1314, Alice \\ Email: smkangethe@yahoo.com \\ Mr Thanduxolo Nomngcoyiya
}

MSW student, University of Fort Hare, P/B X1314, Alice

Email: 201006645@ufh.ac.za.tnomngcoyiya@gmail.com

\author{
Doi:10.5901/mjss.2014.v5n14p458
}

\begin{abstract}
The aim of this article is to explore the role of selected cultural practices and assess how they can be a panacea in mitigating the state of social vices in South Africa. The article uses a review of literature methodology. Findings indicate that Africans were hoodwinked by white people to abandon their cultures for western based cultures; African cultures continue to weaken as they succumb to forces of westernization, eurocentrism, modernization, civilization and globalization; Africans have realised that the cultures they abandoned such as virginity testing, sexual mores and taboos; and circumcision could be a panacea in mitigating some of the societal ills such as moral decadence and HIVIAIDS. The article urges for a resuscitation of cultural practices such as virginity testing, thigh sex (ukumetsha), circumcision and teachings that accompanied initiation schools; and societies to undergo an attitudinal and cultural paradigm shift that will consider the invaluable aspects of cultures that can effectuate and facilitate mitigation of social ills in African countries such as South Africa.
\end{abstract}

Keywords: Virginity testing (reed dance), circumcision initiation schools, African Renaissance, thigh sex, moral decadence, cultural custodians, state of anomie.

\section{Background and Introduction}

With day to day scaring electronic and print media reports of different kinds of crime, tensions and fights among the spouses, suicidal tendencies, increased cases of abortion and unwanted pregnancies, increased indulgence in drugs and other illicit aspects of lives such as sexual orgies, reports of possible corruption, then apparently South Africa appears to be increasingly sliding into a state of normlessness or what Emile Durkheim called anomie (Thorlindsson, Thorolfur, and Jon Gunnar Bernburg, 2004). The indulgence in these vices is undesirable because they immensely undermine the quality of life that people should be enjoying. Although many African countries are falling prey to these vices as they fast abandon or sacrifice their cultures to follow western based cultures or ways of life, South Africa leads the pack in embracing eorocentrism and western ways of living more than other countries of Africa by some of these vices. Further, these vices may be a result of enormous and phenomenal changes ushered in by transition of South Africa to democracy (Beall, Jo and Gelb, Stephen and Hassim, Shireen 2005). Some of these changes have given birth to moral crisis that if not addressed stand the chance of negatively affecting the lives of the people in large scale (Kaarsholm 2006). To this end, Kaarholm (2006) further postulates that social challenges such as crime and preponderance of poverty have largely become a burden on many communities and thereby demoralizing people's worth, value and dignity. This state of moral crisis to a greater extent informs the prevalence of HIVIAIDS and increased state of moral decadence in South Africa (Barnett \& Whiteside 2006; Ramphele 2008). With global statistics indicating that the country is the refuge of the highest number of people living with HIVIAIDS, this has added sorrow and agonies among many people as they think of possible early death, with or without the working miracles of the ARVs (Barnett \& Whiteside, 2006; Ramphele, 2008).

In South Africa just like in many other countries, most of these social vices are a result of breakdown of family and cultural values that saw children and the youth stick to cultural norms and values that made careless indulgence in activities such as alcohol and illicit sexual affairs a difficult phenomenon. Today, the society appears to have undergone a negative paradigm shift in which the youth no longer respects the elderly, no longer prescribe to societal norms of do's and dont's; parents are no longer strong in shepherding their children to maintain discipline and uphold moral chastity for 
the well being of societal health. The families appear to be in disarray, without any predictable social direction, and without any uncompromisingly reflective norms and values. Apparently, the parents can be squarely blamed for abdicating their cultural and religiously endowed responsibility of nurturance and shaping the children to be good and responsible citizens of their countries (Kang'ethe \& Rhakudu, 2010; Kang'ethe \& Gaseitsiwe, 2012).

In South Africa as in many other countries of the world today, the behaviour of the young boys and girls is pathetic. They no longer have the motivation or desire to preserve their sexual purity which used to be a strategy to protect them from different sexual transmitted infections (STIS) such as HIVIAIDS, unwanted pregnancies, abortion, etc (Adebule and Ibimiluyi, 2012). Statistics by Health System Trust in South Africa indicates the increased rate of termination of pregnancy among school girls in South Africa ranging from 26, 455 in 1997 to 53, 967 in 2001 (Patel and Myeni, 2008). This is an indication of a weakening state of cultural values and sliding into a state of moral decadence. This needs to be revisited if the situation is to change. To this end, Kang'ethe (2009a) regards culture as the societal mirror due to its significant invaluable practices as it provides people a general design for living, personality development, shaping and moulding of behaviour as well as instilling discipline, respect, norms and values. Maleche and Day (2011) are of the view that culture should be understood in terms of retaining and jealously guarding and maintaining the communal system of living in which the accumulated knowledge and skills as well as the values considered invaluable and sustainable are passed on to the on coming generations, or to children and youth. Culture in essence refers to aspects of the social environment that control human conduct. This view is evident with this cultural adage "umntu ngumntu ngabantu" which means that to be human is to relate with others in a meaningful way. This is an indicator that culture in any society is characterized by sharing the rituals and preservation of societal identity (Afolayan 2004)). Culture in African society is very synonymous with the value of "Ubuntu" (humanity) which can be referred to as the spirit of selflessness, spirit of empathy, spirit of upholding norms, tradition, standards and values of society, the spirit of respect for oneself and respect for others; as well as spirit of parting with what one immensely treasures (Kang'ethe \& Rhakudu, 2010). Without culture, people lose their norms and a sense of direction in their lives. Hence, culture is a fulcrum to shape the behaviour of people in societies (Afolayan 2004; Kang'ethe, 2013a).

Although South Africans in a way are increasingly drifting away from their culture and easily succumbing to the forces of globalization, westernization, civilization, modernization, and eurocentrism (Kang'ethe, 2009b, 2013b), apparently these researchers believe that South African's various rich, diverse and unique cultures could be used to mitigate different social vices that are slowly and horrendously demolishing the society's moral fibre and of many of its social functioning. The aim of this article is to explore how specific cultures can be used to mitigate social vices in South Africa. In doing this, these researchers will focus on HIVIAIDS pandemic, one of the social vices that can be addressed using specific cultures.

\section{Problem Statement}

Apparently, South African government, civil societies, non-governmental organizations are day- in day- out engaged in seeking solutions to address different social vices such as teenage pregnancy, abortion, drugs, crime and HIVIAIDS pandemic in particular. Sadly, cases of HIVIAIDS and teenage pregnancies appear to burgeon every day. Perhaps this correlates with the fact that South Africa has the highest number of people living with HIVIAIDS (PLWHA) globally with 5.4million - 5.8 million living with HIVIAIDS.

Despite the efforts to tackle these vices, apparently there has not been much success. This leaves room for other possible alternatives to be employed. Since cultures have been identified as factors that could be used to mitigate some of the vices such as HIVIAIDS through penile male circumcision, these researchers would like to widen the scope of exploring different ways of using cultures for example to bolster the behaviours of the youth in order to reduce or mitigate cases of teenage pregnancy and other associated ramifications. The use of cultures can be a panacea because all communities have cultures. Apparently and appreciably, the use of cultures as problem solving platform can be a less expensive endeavour.

\section{Methodology}

This article has benefited immensely from an extensive review of literature on aspects of culture that can be useful in mitigating various social vices that wreak the moral fibre of the societies in South Africa. Journal articles, books and different publications that have written extensively on different ethnic cultures in South Africa have immensely shaped this article. Review of relevant and diverse literature is hoped to bring to the fore some cultural interventions that may have been overlooked in African continent and South Africa in particular but proved to be useful in other nations, although 
social and political contexts and environments may not be the same.

\section{Theoretical Framework}

The issue of the fundamental aspects of culture that can be utilized to mitigate various social vices that seem to wreak and undermine the moral fibre in our societies can be explained by eclectic theoretical perspectives such as anomie theory which explains how social structures contribute to the creation of deviance; and also socio -cultural perspectives which provide a clear insight on the importance of cultural influence and its role in shaping human existence. These two theoretical frames, the theory of anomie and social cultural perspectives are discussed here below.

\subsection{The theory of Anomie}

Anomie refers to the breakdown of social norms and a condition in which those norms would no longer be able to control the activities of societal members (Moyer, 2001). This perspective conforms or can be equated to the theory of deviance which explains a phenomenon in which behaviours are contrary to the common culturally accepted norms and values in the society. According to this theory, deregulation in society sets a stage for anomie. This is where there are no clear rules or norms to govern the society. This indicates that a state of lawlessness may characterize such a society. Therefore, due to lack of strong cultural limitations and delimitations to influence people's behaviour in South Africa, societies are characterised by anomie. Perhaps this explains why South Africa is associated with increased spate of variegated and complex kinds of crime that has tainted its name, whether nationally, regionally or globally.

\subsection{Socio-cultural perspective}

Socio-cultural perspective taps into indigenous knowledge systems acknowledging that people from within a cultural group are experts on their own cultural systems and practices (Swartz, Duncan, De la Rey and Townsend, 2011). They further argue that this perspective adopts an attitude of cultural relevance, and that the behaviour needs to be assessed according to the culture in which it commonly occurs. Mbiti (1986) is of the view that traditional practice is not individualistic in its nature, but a communal practice which has to be understood within the historical context of an "ubuntu" culture where the identity of each person is respected equally. It is for this reason that these researchers feel justified to look at how different cultural practices can be used to mitigate various social vices in South Africa. They believe that the effective utilization of some of the ethnic groups' cultural practices may in one way or the other provide solutions if given an equal opportunity and recognition as the interventions of the west.

\section{Selected Cultural Practices in South Africa and How They Can Mitigates Social Vices}

\subsection{Sexual mores and taboos}

In yester years, or a few decades ago, especially before most African countries got independent, most African cultures were very strong in condemning adolescents' sexual misbehaviour such as premarital sex to the highest degree (Afolayan, 2004). To this end, many cultures had well respected and deep rooted taboos and sexual mores that everybody observed. The do's and dont's were very seriously demarcated and heavy penalties were prescribed in the event that one was found to transgress the norms and such values (Kang'ethe, 2013a,b; Afolayan, 2004; Maleche and Day, 2011). Due to this scenario and condition, premature sexual encounters especially that resulted to pregnancy were taken seriously with the culprits becoming the village laughing stock. Sometimes, those who transgressed these norms were estranged so that the village could have its state of sanity and order. Because of the realization of the biological processes involved in the bodies of especially the adolescents, the youth in some communities were clandestinely advised to consider the alternative of penetrative sex encounters such as thigh sex or "ukumetsha" during the false pretence marriages between both sexes (Mudhovozi, Ramarumo and Sodi, 2012). This paper will discuss the dynamics of these cultural practices that ensured sexual state of chastity. Such practices includes "ukuhlolwa kweentombi" (Xhosa initiation for young girl's for sexual preservation); Domba (Venda initiation school for girls); and "umhlanga" (Zulu virginity testing initiation event for girls) will be explored: 


\subsection{Xhosa cultural initiation for young girls}

As a cultural measure to maintain girls' sexual chastity, Xhosa ethnic group that occupy most parts of the Eastern Cape Province practised "Ukuhlolwa kweentombi" or circumcision for young girls. This cultural practice was largely prevalent in places such as Mount Frere, Ntabankulu in Eastern Cape Province. This cultural practice proved useful in terms of preserving girls' virginity, instilling discipline, self-respect, upholding societal values and norms as well as keeping African culture abreast. According to Feni (2013) in the Daily Despatch Newspaper dated $12^{\text {th }}$ October, the ancient custom of "ukuhlolwa kweentombi" played a fundamental role in inspiring girls to remain sexually clean and the traditional custodians believe it also inculcated self-respect in girls. He further argues that "ukuhlolwa kweentombi" if resuscitated could be instrumental in safeguarding girls' sexual cleanness before marriage. This would be important to prevent unwanted teenage pregnancy, and to mitigate the spread of HIVIAIDS pandemic and other sexually transmitted diseases. It is also a cultural value that could keep promiscuity at bay. With today's culture of promiscuity, excessive intake of alcohol by both the young and the old, addictive abuse of dangerous drugs such as Mandrax, dagga, heroine, cocaine, ectasy in South Africa as in many other countries of Africa (Kang'ethe 2014), cultural values such as the one described above could help change the status quo. But this would only be possible if parents, leaders and cultural custodians could take a bold step in challenging the different structures of the society to undergo a paradigm shift that will see both adults and children change their behaviours. Perhaps parents cannot escape the blame for not setting emulable standards of behaviours to their children. This is because as adolescents talk of boyfriends, girl friends, boozing and partying, some parents are still behaving the same. Therefore, it would be difficult for such parents to lay ground for their children to change their behaviours to be good citizens of the country. To say the least, the adults of today are not necessarily providing an emulative culture to the youngsters in terms of behavior.

To ground culture into a state of immense value, the cultural rites such as girls' circumcision and virginity testing have had a boost through the Eastern Cape House of Traditional Leaders (Feni, 2013) denouncing the view of the antivirginity testing voices who indicate that the practices are archaic, barbaric and violates the girls' human rights (Kang'ethe, 2009b, 2013a,b). Rather, the leaders yearn with gusto and nostalgia the resuscitation and regeneration of such cultural values that would turn around the current wave and state of moral decadence sweeping across many countries of Africa (Adebule and Ibimiluyi, 2012). The leaders also argue that the cultural value of virginity testing go beyond just testing as it offers an opportunity for sex education and also education on how one can become a good citizen and a good wife that the society would feel proud of. It is therefore critical that if people find sense in these cultural practices, they should solidly support them, either through oral advocacy and lobbying for them, or through writing and publication. These researchers see a lot of social capital embedded in some of these cultural practices (Kang'ethe, 2013a, b). They would therefore support the traditional custodians of cultures in advocating for the resuscitation of these rites. In these researchers' contention, societies should negotiate for the processes that will bring back the invaluable glory of having societies whose girls are free from HIVIAIDS and other sexually transmitted diseases. Perhaps the fact that South Africa is a refuge to close to 5 million people infected with the HIVIAIDS should be one of the countries working round the clock to ensure that measures to dissuade people from all the vulnerabilities associated with HIVIAIDS are strengthened (Barnett \& Whiteside 2006; Ramphele, 2008).

\subsection{Domba (Group initiation schools)}

Domba refers to group initiation school carried out for the girls by the Venda community of South Africa. The cultural rite entailed a lot of teaching and activities that were usually carried out in private seclusion or initiation schools. Infact in most countries that had initiation schools, they were always carried out in areas with least disturbances, usually in the waste land, mountains, or inhabited land. Perhaps these are the areas believed to be associated with appeasing the communities' deities (Kang'ethe \& Rhakudu 2010; Afolayan 2004). The situation parallels with the Botswana initiation ceremonies of Bogwera (for boys) and Bojale (for girls) that were were/and are still today being carried out in areas of seclusion away from the inhabited land in the mountains and wasteland.

The Domba initiation school served as an educational institution in which cultural norms and values were transferred from the elderly or the custodians of culture to the young girls. This took the medium of dancing and music (Kruger, 2004). Kruger (2004) further advanced the view that this initiation school encompasses vast amount of information regarding the aspect of adulthood which is imparted to young girls through dance and dramatic representation. According to Makaula (2010), such customs do not necessary address issues related to young girls only in song and dance, but the process also involves the morals embedded in them that are instrumental in moral architecture of the young girls. These researchers wonder whether the government and institutions of learning are today 
deeply concerned in moral education. Although most schools in many countries have in their curriculum religious education that teaches morality and the need to be well mannered, maintenance of sexual chastity, in South Africa the curriculum does not have a component of religious education. This could perhaps explain the state of moral decadence in both primary and secondary schools where many pupils of grade 12 have already been exposed to sexual encounters (Palen et al., 2008).

\subsection{The culture of virginity testing among the Zulus (Umhlanga)}

Perhaps this is the cultural rite that has attracted a lot of debate in South Africa with the human rights groups calling for its total annihilation or discontinuance (Kang'ethe, 2013b). However, these researchers are of the opinion that the human rights bodies are part of the advocacy cahoots of the western countries that are determined to totally demonize African's indigenous knowledge systems and cultures that are proving to be a panacea to solve Africa's problems (Kang'ethe, 2011). Emphasis on using these cultures is tantamount to having Africa solve their problems from home bred solutions and should be encouraged by especially the African elites.

Umhlanga, or "reed dance" is a culture also practised by South Africa's neighbours such as Swaziland. In South Africa, it has historically and culturally been practised by the Zulus under the patronage of their King. Today, the drive, zeal and emphasis to continue with the culture of virginity testing in South Africa is coming from the current Zulu King, Goodwill Zwelithini (Kang'ethe, 2014b). To this end, Commission on Gender Equality (Mohlaka, 2000) expresses the view that this cultural practice educates girls not to allow boys and men to take away their pride by having sexual intercourse with them before marriage, but also how to learn ways to avoid men and their tricks. It further argues that this cultural practice could also be instrumental in delaying the adolescents' sexual engagements. This would be a plus in the battle against HIVIAIDS and sexually transmitted diseases. It is also a strong deterrent to early sexual debut and therefore could be an effective process in reduction of teenage pregnancy which result in many young girls being school dropouts (Palem et al. 2008). According to South African Human Rights Commission (2005), virginity testing is a contested domain. There are those who are for it to continue and those who will like the practice annihilated altogether. The proponents of this cultural practice view it as one of the interventions to deal with some of the worst social vices the country of South Africa has ever experienced such as HIVIAIDS pandemic, teenage pregnancy, immorality, sexual misbehaviour, etc. The supporters view that strengthening and expediting the resuscitation of this cultural practice as well as allowing it to have tentacles all over the country is long overdue. Such supporters of the practice embrace and commend the efforts of the current Zulu King, Goodwill Zwelithini who has incessantly fought a brave battle to have the cultural rite embraced and accepted by his people and also other government agents (Kang'ethe, 2014a). It is a process that can spur a spate of moral regeneration. According to George (2007), one of the virginity testers Nomagugu Ngobese indicated that this cultural practice is about empowering the girls to abstain sexual intercourse and also having the girls be taught to take a good care of their bodies. Although certain people regard this practice as oppressive towards young girls and indicate that the practice interferes with their privacy, this is when they blindly follow the western based meaning of human rights that most of the Africans are not ready to embrace. Advisedly, Africans should understand the concept of human rights from African lenses to benefit and work for them.

\section{Recommendations/The Way Foward}

\subsection{African Renaissance /The need to go back to the roots}

The notion of African Renaissance from the reflections of former President of South Africa, Thabo Mbeki was definitely not only a call for the mere recognition of Afrocentrism in terms of political and socio-economic ideologies, but the promotion and emphasis on African culture and its contribution towards the forces of international development namely, globalization, modernization and development. According to Bongmba (2004), Mbeki believes that the current generation has been victims of western based ideologies and imperialism and therefore it is high time that Africans rise to take their position by battling with the war of emancipating themselves economically, ideologically and culturally. He further points out that Africans have managed to emancipate women and children from oppression, underdevelopment, and historical dependency that has been a standing feature of African history. In other words, Africans have all the necessary capacity to unleash their potential and tap on their own existing resources such as indigenous knowledge system which includes different cultural practices in addressing the challenges and needs of its societies.

Jenkins (2007) believes that cultures served as a vital informal educational instrument during the pre-colonial era in the sense that the education was community-based facilitated and led by elders of the community. He further highlighted 
that informal education and learning was facilitated through initiation schools where community elders transferred cultural education in cultural learning institutions such as "intonjane" for young girls and in circumcision schools known as "ulwaluko" for young boys. African scholars have to be partly blamed for succumbing to the five pillars of international development, i.e globalization, westernization, civilization, westernization, and eurocentrism, and giving culture a raw deal.

To this end, these researchers believe that there's a need for African scholars to jealously guard not only South African families and communities in particular but the whole African continent from being brainwashed and misled by the westerners. There's a need to go back to the roots and reutilize indigenous knowledge in addressing all these different social vices aforementioned above. This is very synonymous with the phrase "Africans need African solution to deal with African problems". Battle and Cousin (2011) indicate that the African Union (AU) has been using the phrase "African Solutions for African Problems". According to these authors, AU has never suggested that it wants to solve its problems in isolation. Rather it has proposed to international community to consider and recognise African partnership, plans, and proposals into the dynamics of the discovery of solutions to African problems. This also seeks to dismiss the statement which was once made by Bishop Crowther (one of the early convert in 1959) quoted in Mphahlele (2004) that Africa has neither knowledge nor skills to devise plans to harness and develop its vast resources. He further asserted that to claim Africa for the Africans alone is to claim the right for continued ignorance to practice cruelty and acts of barbarity as its perpetual inheritance.

\subsection{The Ministry of Arts and Culture of governments should promote culture and identity}

It is high-time that the ministry of arts and culture especially during this new political dispensation strive towards the promotion and protection of South Africa's indigenous cultural practices. The fact that this right is enshrined in the country's constitution is basically not enough. The Ministry of arts and culture portfolio has a duty to mainstream the aspects of cultural practices that adds value to the well-being of the society. Maleche and Day (2011) highlight that the right to cultural identity is also part of the right to autonomy, which is clearly stipulated in Article 1 of the International Covenant on Civil and Political Rights (ICCPR). They further assert that people have a right under international instruments to uphold their traditional cultural practices which are unique and meaningful to them and have the right to develop them. By this, these researchers mean retaining the invaluable cultural practices that add value to the general society. These practices and values can be instrumental in enhancing the social functioning of people in any society. Such practices such as virginity testing and maintenance of sexual mores and taboos could today be a panacea in keeping sexual promiscuity at bay.

\section{Conclusion}

The place of cultures has to be explored and uplifted as a platform of interventions to solve some of the social vices bedevilling societies in South Africa and other African countries. Maintenance and observation of cultures such as sexual taboos and mores, practising virginity testing (reed dance) and circumcision have been proved to be accompanied by good and positive behaviours that could deter or discourage people's indulgence in social vices such as abuse of drugs and alcohol, prostitution and generally acts of moral decadence that continue to bedevil contemporary societies in many countries of Africa, with South Africa being the most affected. These researchers call for countries to accept to undergo a cultural paradigm shift in which all the progressive aspects of cultures are recalled back and operationalized, while the retrogressive ones are annihilated altogether.

\section{References}

Adebule, SO and Ibimiluyi, FO (2012). An assessment of the prevalence of sexual immorality among the secondary school students in South West Nigeria.Research Journal in Organizational Psychology \& Educational Studies 1(6) 361-365 Rjopes.Afolayan, F. ( 2004). Culture and Customs of South Africa. Westport, Connecticut: Greenwood Press

Barnett, T. \& Whiteside, A. ( 2002). AIDS in the Twenty-First Century. Disease and Globalization. Hampshire: Palgrave Macmillan.

Battle, B. \& Cousin, E. ( 2011). African Solution for African Problems (ASAP), Environmental Issues, August 31, 201.

Beall, Jo and Gelb, Stephen and Hassim, Shireen (2005). Fragile stability: state and society in democratic South Africa. Journal of Southern African studies, 31 (4). pp. 681-700. DOI: 10.1080/03057070500370415

Bongmba, E. K. ( 2004). Reflections on Thabo Mbeki's African Renaissance. Journal of Southern African Studies, Vol. 30 (2), June, 2004: pp.291-316.

Commission on Gender Equality (CGE) 2000. Consultative Conference on Virginity Testing, Richards Bay, 12-14 June. 
Feni, L. (2013). Ancient ritual promotes honour of maidens. Saturday Dispatch, Weekend, October 12 - Saturday: pp.16-17.

George, E. R. (2007). Like a Virgin? Virginity testing as HIVIAIDS Prevention: Human Rights Universalism and Cultural Relativism Revisited, Law Journal: 17-19.

Jenkins, M.W. (2007). Curriculum recontextualising using gardens for the Health Promotion in the Life Orientation Learning Area of the Senior Phase, Master of Education (Environmental Education), Rhodes University.

Kaarshom P 2006. Culture as cure: Civil society and moral debates in KwaZulu-Natal after Apartheid, Popular Cultural Materials and Public Spheres, Special issue of the journal Current Writing, Vol.18 (2), pp.1-13.

Kang'ethe SM 2009a. "Inadequate Male involvement in Health Issues: The cause of gender skewed HIV and AIDs situations in Botswana". In Maundeni, T, Osei-Hwedie, B.Z., Mukaamambo, E. \& Ntseane, P.G. (eds). Male Involvement in Sexual and Reproductive Health. Prevention of Violence and HIVIAIDS in Botswana. Made Plain Communications, Cape Town.

Kang'ethe, S.M. (2009b). Traditional healers as caregivers to HIVIAID patients. Sahara Journal. Vol. 6 (2). September, 2009. Pp.83-91.

Kang'ethe, S.M. (2011). Evidences of indigenous knowledge systems driving care giving in care programmes in Botswana. Fort Hare Papers. Vol.18, pp 5-15.

Kang'ethe, S.M \& Rhakudu, M.( 2010). Religious Education book for form 2. Heinemann Publishers, Gaborone.

Kang'ethe, S.M \& Gaseitsiwe B M.( 2012). Religious Education book for form 3 Botsalano Publishers, Gaborone.

Kang'ethe, S..M. (2013a). The panacea and perfidy of culture as a platform of behavior change with examples from Botswana and South Africa. In the press of Social Work Practitioner, University of Johannesburg, South Africa.

Kang'ethe, S.M. (2013b). The panacea and perfidy of cultural rites of circumcision in African countries: Examples from Kenya, Botswana and South Africa. Eastern

Africa Social Science Research Review, Vol. XXIX, (1): pp.107-123.

Kang'ethe, S.M. (2014a). Exploring Lost and Available Opportunities for Youth Empowerment in selected African Countries. In the press of Journal of social Science

S.M Kang'ethe (2014b). The need to resuscitate the cultural rite of virginity testing as a tool to strengthen the campaign against HIVIAIDS and moral decadence in South African region. In the press of Mediterranean Journal of Social Sciences

Kruger, J. H. (2004). Dance in Venda culture: An introduction, Potchefstroom: p.38

Maleche, A \& Day, E. ( 2011). Traditional Cultural Practices and HIV: Reconciling Culture and Human Rights, Working Paper for the Third Meeting of the Technical Advisor Group of the Global Commission on HIV and the Law, 7-9 July 2011.

Makaula, P. N. ( 2010). Aspect of moral education in Bhaca mamtiseni and inkciyo initiation rituals, (Master of Music Dissertation), NorthWest University: Potchestroom, 1-82.

Mbiti, J.S. (1986). Bible and Theology in African Christianity. Oxford University Press: Nairobi.

Mohlaka, S. B. (2000). Commission on Gender Equality (CGE): Consultative Conference on Virginity Testing. Richards Bay, 12-14 June: pp.12-13

Moyer, T. L.(2001). Criminological theories: Traditional and non-traditional voices and themes. USA: Sage Publications, Inc.

Mphahlele, E. (2004). ES'KIA: African Humanism and Culture Social Consciousness, Literary appreciation education. Johannesburg. RSA: Stainbank \& Association Pty (LTD), pp.25-52.

Mudhovozi, P. Ramarumo, M. \& Sodi, T. (2012). Adolescent Sexuality and Culture: South African Mother's Perspective. African Sociological Review, 16 (2): pp.119-138

Palen L, Smith EA, Caldwell LL, Fisher AJ and Wegner L (2008). Inconsistent Reports of Sexual Intercourse Among South African High School Students.Journal of Adolescent health. Vol 42 Issue 3, Page 221-227. March 2008

Patel, C. J \& Myeni, M. C. (2008). Attitudes towards abortion in a sample of South African female university students. Journal of Applied Social Psychology, 38 (3): pp.736-750.

Ramphele, M. (2008). Laying ghosts to Rest. Dilemmas of the Transformations in South Africa. Capetown: Tafelberg

South African Human Rights Commission (SAHRC) (2005). Harmful Social and Cultural Practices (Section 12), Extract from written submission to the Portfolio Committee on Social Development, August 2004: pp.1-17.

Swartz, L., Duncan, N., Townsend, L. \& de la Rey, C. (2011). Psychology: An introduction. (2nd ed). Oxford University Press: Cape Town.

Thorlindsson, Thorolfur, and Jon Gunnar Bernburg (2004). "Durkheim's Theory of Social Order and Deviance: A Multi-level Test." European Sociological Review 20(4):271-85. 